\title{
Implementation of Supervision Policy for Local Private Television Station Broadcasting by Regional Broadcasting Commission
}

\author{
Andriansyah $^{1}$, and Taufiqurokhman ${ }^{2}$ \\ \{andriansyah@dsn.moestopo.ac.id ${ }^{1}$ \& taufiqurokhman@dsn.moestopo.ac.id ${ }^{2}$ \} \\ ${ }^{1,2}$ Faculty of Social and Political Sciences Universitas Prof.Dr. Moesopo (Beragama), Jalan \\ Hanglekir I Number 8 Jakarta, Indonesia
}

\begin{abstract}
The research objective was to see the extent to which the local broadcast television station supervision policy was implemented by the Regional Broadcasting Commission. Regarding the process of regulating broadcasting, licensing at the decision stage of the Broadcasting Commission. which is an independent state institution in Indonesia. The research methodology uses a qualitative method with descriptive research, using a functional theory approach with the location of research in the Banten Province Regional Broadcasting Commission. Research descriptions are designed to gather information about ongoing conditions and examine the causes of a particular symptom. Taking informants is based on criteria: having knowledge of the problem chosen, knowing the procedures and authority and want to be interviewed. The results of the study state that the conditions and stages for local private television station broadcasters must comply with the applicable rules. So that the supervisory policy sets broadcast program standards and broadcasting behavior guidelines; sanctions, implementation of regulations; coordination and cooperation with the Government, broadcasting institutions, and the community by the Regional Broadcasting Commission can be carried out optimally.
\end{abstract}

Keywords: Policy Implementation, Broadcasting Supervision of Regional Broadcasting Commission, Local Private Television Station

\section{Introduction}

The Broadcasting Code of Conduct and Standard Broadcasting Program are basically designed based on the mandate given by the Law of the Republic of Indonesia Number 32 of 2002, concerning Broadcasting to the Indonesian Broadcasting Commission. In Article 8 of the Law it is stated that the Indonesian Broadcasting Commission has the authority to set the Broadcast Program Standards and Broadcasting Code of Conduct, as well as provide sanctions for violations of the Standards and Guidelines, (Banten Province Regional Broadcasting Commission, Strategic Plan, 2011). The development of communication and information technology has given birth to an information society that has greater demands for the right to know and the right to obtain information. Information has become a basic necessity for the community and has become an important commodity in the life of the community, nation and state. For television, Televisi Republik Indonesia is the first television station to air in Indonesia. First broadcast on August 17, 1962, Televisi Republik Indonesia became one of the ambitious projects of Soekarno who at that time wanted his country not to be called backward and outdated, and at that time the Republic of Indonesia Television was projected to welcome 
the implementation of the Asian Games IV which was the first held by Indonesia. Then, in the 1990s a private television appeared which was pioneered by Rajawali Citra Televisi Indonesia Television Station (RCTI). Then Indonesian Education Television (TPI), Surya Citra Televisi Indonesia (SCTV), ANTV and Indosiar. Basically these stations were one of the business developments of the Suharto family, which in terms of business indeed controlled business space in Indonesia. In its development, televisions, especially private television, are geographically centralized in the capital city of Jakarta, including Rajawali Citra Televisi Indonesia Television Station, Indonesian Education Television, Surya Citra Televisi Indonesia, ANTV Television Station, Indosiar Television Station, Trans TV Television Station, TV 7, Lativi Television Station, Global TV Television Station and Metro TV Television Station. All have national broadcasting rights. The position of Jakarta as the center of national television has become a separate phenomenon for the quality of television itself, such as the emergence of cultural generalization and broadcast programs. Many television programs or soap operas take a background in the city of Jakarta because in addition to not consuming expensive production costs, they can also be packaged quickly and efficiently.

After national private television, which is quite interesting is the emergence of local television. Apart from the conflict of interest between the government and the existing television industry capitalism, the local television station was born with the passion of the existing regional autonomy [1]. The enthusiasm to become a local media that facilitates their respective local communities, both in terms of information and entertainment, seems to be a jargon that positions local TV as a bright prospect for the advancement of the media world in Indonesia. In the Jakarta area, Jak-TV Television Station, O-Chanel Television Station and Space-Toon Television Station appeared. In Bandung, it was colored with the birth of the Bandung TV Television Station, S-TV Television Station, Padjajaran TV Television Station, CT Chanel Television Station. Then in other areas such as Jogja TV Television Station (Yogyakarta), Bali TV Television Station (Denpasar), Pro TV Television Station (Semarang), J-TV Television Station (Surabaya) as Jawa Pos Product. (http://deniborin.multiply.com/journal/ item/40/TV_Lokal_dan_Isu_Lokal, accessed on 12 December 2010).

In Banten Province there are seven local Television Stations, namely Radar TV Station, Tegar TV Station, Krakatau TV Station, and Siger TV Television Station. The local television station has started broadcasting and the broadcast range is quite extensive. In the world of broadcasting, especially television broadcasting, there needs to be supervision from an institution. Supervision of broadcasting institutions is very important, especially supervision of broadcast licenses because currently there are several broadcasting institutions, especially television, which have broadcasted but have not had broadcast permits. With the supervision of the broadcasting institution. Especially television that does not have a broadcast permit can be curbed. The Indonesian Broadcasting Commission is an independent state institution that regulates broadcasting matters at the center and in regions whose duties and authorities are regulated in Law Number 32 of 2002, as a manifestation of the role of the public in the broadcasting sector. In carrying out its functions, duties, authorities and obligations, the Central Indonesian Broadcasting Commission (KPI) is overseen by the People's Representative Council of the Republic of Indonesia, and the Regional Indonesian Broadcasting Commission is supervised by the Provincial Representative Council. The Indonesian Broadcasting Commission has the duty and obligation: (a) guarantee the community to obtain proper and correct information; (b) in accordance with human rights; (c) participate in regulating broadcasting infrastructure; (c) participate in building a healthy competitive climate between broadcasting institutions and; (d) related industries; (e) 
maintaining a fair, equitable and balanced national information order; (f) accommodating, researching, and following up complaints, objections, and criticisms; (g) public appreciation for broadcasting; ( $\mathrm{g}$ ) compile guarantees of human resource development planning; (h) professionalism in broadcasting.

Broadcasting Law Number 32 of 2002 is the main basis for the establishment of the Indonesian Broadcasting Commission. His enthusiasm is the management of the broadcasting system which is the public domain must be managed by an independent body free from investor interference and the interests of power. In contrast to the spirit in the previous broadcasting law, namely Law Number 24 of 1997 Article 7 which reads "Broadcasting is controlled by the state whose guidance and control is carried out by the government", indicating that broadcasting at that time was part of the instrument of power used to solely for the interests of the government. Since the enactment of Law No. 32 of 2002 there has been a fundamental change in the management of broadcasting systems in Indonesia, which in essence is the spirit to protect people's rights more evenly.

The Research Objectives are in accordance with the research problems above, so the objectives to be achieved are to find out the role of the Banten Province Regional Broadcasting Commission in Banten in overseeing broadcasting operating permits at local private television broadcasters in Banten Province. In addition, the purpose of writing this research is as input as well as being a guideline for broadcasting behavior and broadcast program standards for stakeholders, including academics who are indeed involved in the issue of the Regional Broadcasting Commission [2].

The standard of broadcasting guidelines is as stated in Article 3 of the Broadcasting Law of 2002, which can be realized, namely: '. . . strengthening national integration, building the character and identity of a faithful and pious nation, educating the nation's life, advancing public welfare, in order to build a society that is independent, democratic, just and prosperous. . . " As mandated by Article 48 of the Broadcasting Law of 2002, the Broadcasting Code of Conduct was prepared by the Indonesian Broadcasting Commission based on: Religious, moral, and applicable regulations, as well as other norms that apply and are accepted by the general public and broadcasting institutions.

The usefulness of conducting research includes: (a) Theoretically it can be used as a reference for further research in knowing the implementation of the policy of supervision of local private television stations, especially for academics or researchers who want to know more deeply in the implementation by the Regional Broadcasting Commission. Regarding the licensing process for the operation of broadcasting and its stages with local private television broadcasters; (b) practically, this research is expected to be a contribution of the author's thoughts as information and knowledge material for academics and students and students who will take research on the implementation of the Regional Broadcasting Commission's supervision policy in overseeing broadcasting permits and the stages of implementation for private television broadcasters local.

\section{Methodology}

The research methodology uses qualitative method with descriptive research. This type of descriptive research is designed to gather information about current real conditions (while going on). Understanding of qualitative research according to Miles and Huberman (1992) [3] in Basrowi Sudikin states that one of the research procedures produced descriptive data in the form of speech or writing and the behavior of the people observed. Through qualitative research, researchers can recognize subjects and feel what they experience in everyday life. 
The main purpose in using this method is to describe the nature of a situation that is temporarily running at the time the research is conducted, and examine the causes of a particular symptom

Whereas according to Whitney in Nazir, (1988) and Miles \& Huberman (1992) [3], descriptive research method is fact finding with the right interpretation. Descriptive research studies the problems in society, as well as the procedures that apply in society and certain situations, including about relationships, activities, attitudes, views, and ongoing processes and influences from a phenomenon. Descriptive research has characteristics: (1) related to the situation that occurred at that time; (2) describing only one variable or several variables but described one by one; (3) the variables studied are not manipulated or there is no treatment [4].

This research is a study that examines "Implementation of Local Private Television Station Supervision Policy by taking research locations in the Regional Broadcasting Commission in Banten Province". The purpose of the research is how to describe or describe in detail about certain phenomena so that a conclusion can be drawn and also a method used to describe a particular situation or population that is systematic and actual factual. In other words, the purpose of descriptive research is to describe a current set of events or conditions of the population. Whereas according to G. Tan and Koentjaraningrat, (1973) [5], mentioning descriptive research aims to describe precisely the characteristics of an individual, condition, symptom or certain group or determine the frequency or spread of a symptom of a certain relationship between one symptom and another symptom in society [5].

Research according to Sanapiah Faisal (1990) [6] will try to explain, manage, describe and interpret the results of research by compiling words into sentence descriptions in response to the problems to be studied and through qualitative descriptive data we can understand and follow the flow of events chronologically, assessing causes effect and obtain various facts and data [4].

\section{Result And Discussion}

In discussing the results of the study the author will first explain the functions and duties of the Indonesian Broadcasting Commission and the Regional Broadcasting Commission in carrying out their authority, namely: (1) The Indonesian Broadcasting Commission at the Indonesian Government Center in carrying out its duties is supervised by the Republic of Indonesia Parliament Whereas the Regional Broadcasting Commission is supervised by the Provincial Regional Representative Council; (2) In the Broadcasting Law Number: 32 of 2002, in Article 8, Paragraph (1) states, the Indonesian Broadcasting Commission as a manifestation of the role of the community functions to accommodate the aspirations and represent the interests of the broadcasting community; (3) In Article 8, Paragraph (2) In carrying out their functions as referred to in paragraph (1). While the Indonesian Broadcasting Commission has the authority: (1) to set standards for broadcast programs; (2) compile regulations and establish guidelines for broadcasting behavior; (3) supervise the implementation of broadcasting behavior rules and guidelines and broadcast program standards; (4) provide sanctions for violations of rules and broadcasting behavior guidelines and broadcast program standards; (5) coordinate and / or cooperate with the Government, broadcasting institutions, and the community. (Law Number 32 of 2002, Article 7). Next the author will explain about the implementation of broadcasting carried out by private television stations in Indonesia below. 


\subsection{Private Television Station Broadcasting}

Television broadcasting is a media of hearing mass communication, which channel ideas and information in the form of sound and images in general, both open and closed, in the form of regular and continuous programs. This is in accordance with the social changes that have taken place in Indonesian society in understanding communication with the public [7]. Furthermore, the author will explain about television in Indonesia as below:

\subsubsection{Television Broadcasting in Indonesia.}

Television stations that were originally seen as toys or a serious invention or something that contributed to social life, then served as a service tool. In essence, television was born by utilizing all existing media. The other important thing in the history of television development is the strict regulation, control or licensing carried out by entrepreneurs [8] Mass media television communication is the process of communication between communicators and communicants (mass) through a means, namely television.

\subsubsection{Television Broadcast Program in Indonesia.}

Television stations every day present various types of television broadcast programs that are very numerous and the types are very diverse. Basically anything can be used as broadcast material to be broadcast on television as long as the program is interesting and liked by the audience, and as long as it does not conflict with decency, applicable laws and regulations. Managers of broadcasting stations are required to have as much creativity as possible to produce various interesting programs. Various types can be grouped into two major parts based on the type of information programs (news) and entertainment programs (entertainment). Program information is then subdivided into two types, namely hard news (hard news) which is the latest news report that must be immediately broadcast and soft news (soft news) which is a combination of facts, gossip, and opinions.

\subsubsection{Local Private Television Broadcasting in Indonesia.}

Local private television is a listening mass communication media that channel ideas and information in the form of sound and images in general, both open and closed, in the form of regulated and continuous programs, and are commercial in the form of Indonesian legal entities, which only provide television broadcast services and its reach is limited to certain regions.

The development of local private television stations will be explained below:

\subsubsection{Development of Local Private}

Television Stations. On his journey from the beginning to the present, Law No. 32/2002 concerning broadcasting has not yet obtained definite clarity, especially in regulating broadcast area boundaries which implies that national TV to reduce its capacity and coverage area. Many parties who oppose this law, especially from the owners of private TV who have already invested high in their television, the law is meant to limit their business space. Because of the emergence of conflict, the consequence is that the broadcasting law is still unclear. Apart from the conflict of interest between the government and the capitalism of the existing television industry, local TV was then born with the passion of existing regional autonomy. The enthusiasm to become a local media that facilitates their respective local 
communities, both in terms of information and entertainment, seems to be a jargon that positions local TV as a bright prospect for the advancement of the media world in Indonesia. As its position as regional media, even in its presentation and packaging, local TV tends to display and prioritize regional problems, both from the issues brought and from the language used. In addition to the use of language, in the content of the news also the program is a local TV program focused on discussing local problems in their respective regions. Although it has distinctive features in terms of packaging issues and languages, in its development, local TV still has not been able to become an alternative to national TV that has been airing as a way of communication with the public [9]. This can be seen from the format of the program which tends to be the same, the creative power that is expected to not be able to be fulfilled innovatively. The phenomenon of tail tailing in the world of television is actually not a foreign matter, this does not only occur on local TV but in fact it also occurs among national TV itself. The limited investment and weak competitiveness of national TV have become a separate obstacle for local TV to compete with national TV, this has resulted in local TV difficulties in developing themselves, (www.kpi.go.id and http: //kontakpublik.multiply. com / journal / item / 33 / Mencermati_Bisnis_accessed on December 10, 2017).

\subsubsection{Popularity of Local Private Television Stations.}

The popularity of local TV in the midst of people who are far behind compared to national $\mathrm{TV}$ is a factor for the lack of sponsors and advertiser investment to participate in supporting local TV, (Televisi_Lokal_di_Indonesia, Aulia Andri, accessed on September 17, 2010). Capital factor is one of the obstacles that limits the performance of most existing local TVs, but if the government in this case is more assertive in regulating and implementing regulations such as those covered by the broadcasting law that regulate broadcast areas, a little development of local TV will be helped, because the concentration of local TV from both market segmentation and advertising will be maintained. Media, such as in the form of TV, must be seen as a tool to educate society, not just a business aspect. Along with the development of the television world in Indonesia, more and more television stations are emerging, (http://www.suarakomunitas.net/profil/jrkl/, accessed on December 12, 2017). From its origin, only state-owned television stations, namely TVRI, then developed and emerged various national private television stations. Over time the development of the world of television in Indonesia also developed marked by the emergence of various local televisions whose broadcasts were not national scale, but only local scale. (http: // fauzyalfalasany. blogspot.com /2010/01/perkembangan-tv-lokal.html accessed on September 7, 2017).

\section{Functional Structural Theory Approach Research}

Also popular functional theory is called integration theory or consensus theory. The main purpose of loading this integration, consensus, or functional theory is nothing else so that the reader is more clear in understanding society in an integral way. The functional approach considers the community to be integrated on the basis of the agreement of its members on certain social values. These general agreements have the power to be able to overcome differences of opinion and interests among community members. Society as a social system is functionally integrated into a form of equilibrium. Therefore, the thinking flow is called Integration approach, order approach, equilibrium approach or structural functional approach [10] In the beginning the structural functional theory was inspired by classical thinkers including Socrates, Plato, Auguste Comte , Spencer, Emile Durkheim, Robert K. Merton, Talcott Parsons, and others. They explicitly and in detail describe how the functionalism 
perspective views and analyzes social and cultural phenomena. The author will explain in depth about the study of analysis from the theory of functional Structures below:

\subsection{Characteristics of Functional Structural Perspectives.}

This theory emphasizes order and ignores conflicts and changes in society. The main concepts are function, dysfunction, latent function, manifest function, and balance (equilibrium) Wallace and Alison say, that: "Functionalists, as we have seen, look at societies and social institutions as systems in which all the parts depend on each other and work together to create equilibrium. They do not deny the existence of conflict; but they believe the society develops ways to control it, and it is these that analyze. Conflict theorists could hardly be more different. Where funcionalists see interdependence and unity in society. Conflict theorists see and area in which groups fight for power, and the control of conflict simply means that one group is able, temporarily, to suppress its rivals. Functionalist see civil law, for example, as a way of increasing social integration; but conflict theorists see civil law as defining at the expense of others (1986). Functionalists (adherents to the functional approach) see society and social institutions as a system in which all parts are interdependent and work together to create balance (equilibrium). They did not reject the existence of conflict in the community, but they believed correctly that the community itself would develop a mechanism that could control conflicts that arose. This is the focus of analysis for functionalists. According to this theory, society is a social system that consists of parts or elements that are interrelated and and mutually integrated in balance. Changes that occur in a part will also bring changes to the other parts. The basic assumption is that every structure in the social system is functional to others [11]. Conversely, if it is not functional, this structure will not exist or will disappear by itself. In extreme terms the adherents of this theory assume that all events and all structures are functional for a society. According to Lauer [12] this theory is based on seven assumptions, namely: (a) society must be analyzed as a whole unit consisting of interacting parts; (b) relationships that are biased are one-way or reciprocal; (c) the existing social system is dynamic; existing adjustments do not need to change the system much as a whole unit; (d) perfect integration in society has never existed, so that in society there always arises tensions and irregularities, but these tensions and irregularities will be neutralized through the institutionalization process; (e) changes will take place gradually and slowly as a process of adaptation and adjustment; (f) change is the result of external adjustments, grows by the existence of differentiation and innovation, and the system is integrated through the ownership of the same values. Based on the description above, it is known that the functional circles view the community as follows: (a) society is seen as a network of groups that work together in an organized manner which works in a rather orderly manner according to a set of rules and values adopted by most of these communities; (b) the community is seen as a stable system with a tendency towards balance, namely a tendency to maintain a harmonious and balanced work system; (c) each group or institution carries out certain and continuous tasks, because it is functional; (d) behavior patterns arise because they are functionally useful [13]; (e) according to functional structural theory, society as a system has a structure that consists of many institutions. Each institution has its own function. Structures and functions, with different complexity, exist in every society, both modern society and modern society and primitive society. For example, school institutions have the function of passing on existing values to the new generation. Family institutions function to maintain the continuity of the development of the population. Political institutions function to maintain the social order so that it runs and is adhered to as it should. All these institutions will interact and adjust to each other which leads to balance. If there is a deviation from the community institutions, the other 
institutions will help by taking adjustments. Between actors with different motives and values give rise to different actions. The forms of interaction are developed so that they are institutionalized. These institutional patterns will become a social system. To maintain the survival of a community, every community needs to carry out socialization of the social system it has.

\subsection{Talcott Parsons's view of Functionality.}

At first Parsons criticized the notion of Utilitarianism which argued that individuals as atomistic actors tended to act rationally, and gave rise to ideas of constructionalism in social integration. Parsons examines more individual behavior in social integration. Parsons examines the behavior of individuals in social system organizations to give birth to social action theory. The position of individuals in the social system always has its own status and role. In a social system, individuals occupy a place (status) and act according to the norms or rules made by the existing system [14]. In every society, according to the view of structural functionalism, there are always certain basic goals and principles. The value system is not only a source that causes the development of social integration, but also an element that stabilizes the socio-culture itself [10].

\section{Conclusions And Recommendations \\ 5.1. Conclusions}

Banten Province's Broadcasting Commission's authority is to set broadcast program standards, compile regulations and establish broadcasting behavior guidelines, oversee the implementation of broadcasting rules and behavior guidelines and broadcast program standards, provide sanctions for violations of rules and broadcasting behavior guidelines and broadcast program standards, coordinate and / or cooperation with the government, broadcasting institutions, and communities in the Banten Province. In implementing the supervision policy of the Regional Broadcasting Commission regulating broadcasting regulations and having a function as a supervisor of the content and content of the media by the public is a form of social change from the community [12]. In this case, the Regional Broadcasting Commission oversees every broadcasting institution and accommodates complaints from the public. Then the Regional Broadcasting Commission conducted a study of violations aimed at monitoring the violations committed by broadcasters nationally broadcasting Law No. 32 of 2002 and Broadcast Broadcasting Program Broadcasting Guidelines established by the Indonesian Broadcasting Commission. The Regional Broadcasting Commission also has the authority to impose sanctions on violations of the Broadcast Program Broadcasting Code of Conduct. Sanctions given are administrative sanctions in the form of reprimand and termination of impressions. In carrying out this task, the Banten Province Regional Broadcasting Commission must enforce the rules in accordance with applicable regulations. Because the implementation of the conclusions from the results of the research of the Banten Province Regional Broadcasting Commission is still not optimal. Because there are still local private television stations in Banten Province, the content of broadcast content and broadcasting permits is still not implemented according to the applicable rules. This shows that the Regional Broadcasting Commission has not explicitly implemented the rules, therefore it is seen that coordination between the Regional Broadcasting Commission and the government, the community as social control has not gone well. Therefore the local private television station in Banten Province needs to increase the rules that apply in accordance with Broadcasting Law Number 32 of 2002. 


\subsection{Recommendations}

The recommendations from the results of research on the supervision of local private television stations in Banten Province are as follows: (1) Banten Province Regional Broadcasters need to increase monitoring capacity of local private television stations, to make it more leverage. And more socializing Law Number 32 Year 2002, concerning Broadcasting. Because more people do not know and understand about the role of the Regional Broadcasting Commission; (2) Banten Province Regional Broadcasting Commission must be more assertive in giving sanctions to broadcasting institutions that have violated broadcasting behavior guidelines and broadcast program standards.

\section{References}

[1] F. Firdaus, "Parade Iklan Politik di Tahun Politik: Polarisasi Penggunaan Iklan Politik Untuk Membangun Citra Menuju Pemilu 2014," Turast J. Penelit. dan Pengabdi., vol. 1, no. 1, pp. 81-94, 2013.

[2] Marbun, Judicial State Administration and Administrative Efforts in Indonesia. Yogyakarta: Liberty, 2007.

[3] M. B. Miles and A. M. Huberman, Analisis Data Kualitatif: Buku Sumber Tentang Metode-Metode Baru. Jakarta.: UI Press, 1992.

[4] R. Kountur, Research Methods for Thesis Writing and Thesis. Jakarta: PPM Publisher, 2003.

[5] Koentjaraningrat, Community Research Methods, Third Edit. Jakarta: Gramedia Pustaka Utama, 1973.

[6] S. Faisal, Penelitian Kualitatif; Dasar-Dasar dan Aplikasinya. Malang: YA3, 1990.

[7] Alimudin, Perspectives on Social Change. Jakarta: Bina Aksara, 1989.

[8] W. Kusnadi, Mass Communication. Jakarta: PT. Rineka Cipta, 1996.

[9] D. McQuail, Mass Communication Theory: An Introduction. Jakarta: Erlangga, 1987.

[10] Nasikun, Sistem Sosial Indonesia. Jakarta: PT. Rajagrafindo Persada, 2000.

[11] G. Ritzer, Sosiologi Ilmu Pengetahuan Berparadigma Ganda. Jakarta: CV. Rajawali, 2009.

[12] R. Lauer, Perspektif Tentang Perubahan Sosial. Jakarta: PT Rineka Cipta, 1993.

[13] Sutaryo, Community Dynamics in the Conflict Perspective. Yogyakarta: FISIP UGM, 1992.

[14] G. Setiardja, Legal Dialectics and Morals in the Development of Indonesian Communities. Yogyakarta: Kanisius, 1990. 